\title{
Sward Structure and Herbage Accumulation of Massai Guineagrass Pastures Managed According to Pre-Grazing Heights, in the Northeast of Brazil
}

\author{
João Virgínio Emerenciano Neto ${ }^{1}$, Gelson dos Santos Difante ${ }^{2}$, Angela Maria Quintão Lana ${ }^{3}$, \\ Nathália Rafaela Fidelis Campos ${ }^{1}$, Emmanuel Lievio de Lima Veras ${ }^{1} \&$ José Dantas Moraes ${ }^{1}$ \\ ${ }^{1}$ Federal University of Vale do São Francisco, Petrolina, Brazil \\ ${ }^{2}$ Federal University of Rio Grande do Norte, Macaíba, Brazil \\ ${ }^{3}$ Federal University of Minas Gerais, Belo Horizonte, Brazil \\ Correspondence: João Virgínio Emerenciano Neto, Federal University of Vale do São Francisco, Av. José de Sá \\ Maniçoba, 56304917, Petrolina, PE, Brazil. Tel: 55-87-99808-1664. E-mail: joao_neto@zootecnista.com.br
}

Received: January 21, 2017

Accepted: February 22, $2017 \quad$ Online Published: March 15, 2017

doi:10.5539/jas.v9n4p155

URL: https://doi.org/10.5539/jas.v9n4p155

\begin{abstract}
The forage sward height measurement is a practical and potential tool for grazing management. Thus, the objective of this study was to evaluate the structure of pasture and forage accumulation related to sward pre-grazing height of Panicum maximum cv. Massai, before being grazed by sheep. The study was conducted in the Federal University of Rio Grande do Norte, Macaíba, Brazil. The treatments were the pre-grazing sward heights at: 35, 40, 45 and $50 \mathrm{~cm}$. The post-grazing height was $15 \mathrm{~cm}$ for all treatments. The interaction between the pre-grazing sward heights and grazing cycles was only statistically significant for light interception (LI) and leaf area index (LAI). The LI had linear and positive effect to the pre-grazing heights in only one of three grazing cycles, with approximately $1 \%$ increase in LI for each centimeter grown in the sward. The total forage mass had linear regression, every centimeter increased in height, there was a correspondent dry matter (DM) increase of $187 \mathrm{~kg} \mathrm{ha}^{-1}$ in forage mass. There was a linear response between leaf blade mass and dead material with sward height. The post-grazing lowest LI was $29.42 \%$ at $42.05 \mathrm{~cm}$ high. The lowest amount of LI was $29.42 \%$ at $42.05 \mathrm{~cm}$ high. The minimum LAI was 0.69 . The top DM and mineral matter (MM) accumulation rate were linear and had 58.32 and $20.46 \mathrm{~kg} \mathrm{ha}^{-1} \mathrm{day}^{-1} \mathrm{MS}$, respectively. Massai guineagrass grazed by sheep must be handled between 35 and $40 \mathrm{~cm}$ high at pre-grazing when associated with post-grazing height of $15 \mathrm{~cm}$.
\end{abstract}

Keywords: LAI, light interception, morphological component, Panicum maximum

\section{Introduction}

Massai guineagrass possesses a higher growth potential under low fertility conditions (Valentim et al., 2001), as it exhibits higher tolerance to acidity, low phosphorus concentration in the soil (Euclides et al., 2008; Cardoso et al., 2016) and other environmental stresses (e.g. drought) when compared to other Panicum cultivars. In addition, it is an important alternative for cultivation in low permeability soils subjected to temporary flooding (Silva et al., 2009). According to Euclides et al. (2008), there are pronounced morphological differences between Massai guineagrass relative to other Panicum cultivars, such as Mombaça or Tanzânia guinea grass. However, it is possible to obtain satisfactory animal performance when swards are adequately managed, which makes this cultivar an option as a pasture diversification strategy.

Forage production during grazing is regulated by abiotic and morphogenetic factors, with the morphogenetic factors being characteristic of the forage species (stem and leaf elongation, appearance and leaf life time). The plant tissues accumulate with the onset and elongation of the leaves. They are subject to aging and senescence, leading to dead material accumulation and eventually decomposition. Leaf blades are subject to defoliation and its frequency and intensity affect the production rate. The amount of removed forage is a product of the growth rate of the new plant tissues and the efficiency of the harvesting process, which is defined as the ratio between the grown forage grazed before entering senescence (Lemaire et al., 2009).

In pastures under rotational stocking method, the definition of the regrowth and occupation periods based on a 
fixed and pre-determined number of days is common (Lima et al., 2013). However, the growth potential of grasses is dependent on climatic conditions, such as temperature, photoperiod and rainfall, resulting in growth rate oscillations between and within seasons. In this way, adoption of this grazing control method has resulted in a wide variation in sward structure attributes, such as forage and leaf mass, leaf area index and sward height, which affect the pattern of forage intake and animal performance (Pedreira et al., 2009; Lima et al., 2013).

The sward surface height has been evaluated and adopted for defining the adequate moment for grazing, or the pre-grazing condition, for the most commonly used forage grasses in cultivated grasslands in Brazil. According to Pedreira et al. (2007), this criterion is highly correlated with sward light interception, allowing herbage to be harvested in the same physiological condition according to variations in its accumulation (Lima et al., 2013). In addition, sward height is an easy and practical tool to guide grazing management in tropical forage grasses (Difante et al., 2010; Euclides et al., 2014). In this context, identifying the ideal sward surface height for each grass is essential to increase herbage production and animal productivity.

The objective of this study was to evaluate herbage accumulation and sward structure of Panicum maximum cv. Massai guineagrass subject to four pre-grazing heights under rotational stocking management.

\section{Material and Methods}

The study was conducted in the experimental area of the Study Group on Forage, located at the Agricultural School of Jundiaí, Campus of the Federal University of Rio Grande do Norte, Macaíba, Brazil (553'35.12" S, $35^{\circ} 21^{\prime} 47.03^{\prime \prime} \mathrm{W}$, and $50 \mathrm{~m}$ a.s.1.).

The climate, according to the Thornthwaite's classification (1948), is sub-humid dry, with water surplus from May to August. Averages of annual rainfall and potential evapotranspiration are 1,048 and 1,472 mm, respectively. Monthly averages of maximum and minimum air temperature and rainfall are shown in Figure 1.

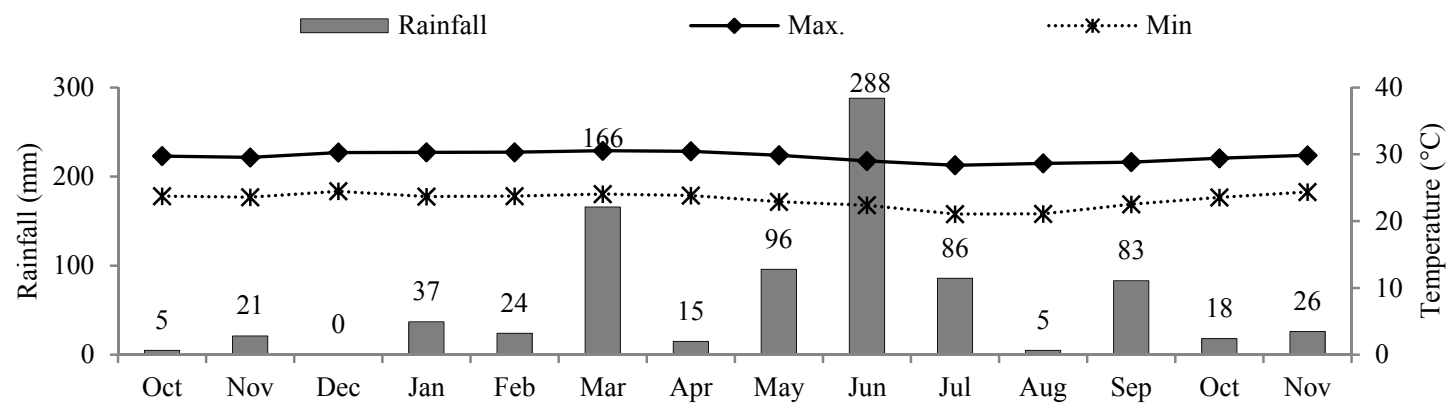

Figure 1. Rainfall, maximum (Max) and minimum (Min) temperature in the experimental area during the evaluations

The experimental area was comprised of four modules with $2,400 \mathrm{~m}^{2}(0.24 \mathrm{ha})$ subdivided into six paddocks of $400 \mathrm{~m}^{2}(0.04 \mathrm{ha})$, totaling $9,600 \mathrm{~m}^{2}(0.96 \mathrm{ha})$. A target sward height was assigned to each module. Treatments corresponded to four sward surface heights at the pre-grazing of: $35,40,45$ and $50 \mathrm{~cm}$. The evaluations were conducted during four grazing cycles (that period that all paddocks in the module were grazed on) from October 2013 to November 2014. The soil was classified as Quartzarenic Neosol (EMBRAPA, 2006). Soil chemical analysis (Table 1) was performed in the soil laboratory of the Agricultural Research of Rio Grande do Norte (EMPARN).

Table 1. Soil chemical composition of the experimental area, in 2011, at depths 0-10 and 10-20 cm

\begin{tabular}{|c|c|c|c|c|c|c|c|c|c|c|}
\hline Depths $(\mathrm{cm})$ & $\mathrm{P}$ & K & $\mathrm{Na}$ & $\mathrm{pH}$ & $\mathrm{Ca}$ & $\mathrm{Mg}$ & $\mathrm{Al}$ & $\mathrm{H}+\mathrm{Al}$ & CEC & $\mathrm{BS}(\%)$ \\
\hline & \multicolumn{4}{|c|}{ - } & \multicolumn{6}{|c|}{ 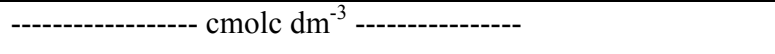 } \\
\hline $0-10$ & 4.75 & 92.25 & 20.25 & 6.03 & 1.07 & 0.45 & 0.00 & 1.06 & 29.04 & 63.50 \\
\hline $10-20$ & 2.25 & 81.25 & 16.75 & 5.85 & 0.68 & 0.20 & 0.00 & 1.20 & 23.61 & 49.18 \\
\hline
\end{tabular}

Pastures were established in 2011 and have been grazed on by sheep since then. There were used 36 test barrow and gilt sheep, as well as extra animals to adjust the stocking rate. The animals were kept in pasture during the 
day (from 08:00 to 17:00 hours) and housed at night in a covered barn with collective pens and free access to water and mineral salt with monensin at all times. Pastures were managed by intermittent (rotational) grazing method, and the beginning of each paddock occupation period was determined by the sward height targets of each treatment. The post-grazing height was $15 \mathrm{~cm}$ for all treatments.

Pastures were irrigated in October, November and December of 2013 and in October and November 2014, in order to keep the plants physiologically active during water shortage periods. A sprinkler irrigation system was used to apply enough water to complement $35 \mathrm{~mm}$ of monthly rainfall. During the experimental period, the swards received top dressing with $75 \mathrm{~kg} \mathrm{ha}^{-1} \mathrm{~N}$ (urea) every two grazing cycles, totaling $150 \mathrm{~kg} \mathrm{ha}^{-1} \mathrm{year}^{-1} \mathrm{of} \mathrm{N}$. The area was kept permanently free of weeds and ant control was maintained throughout the evaluation period.

Sward height pre- and post-grazing measurements were taken randomly at 40 points covering the entire area of each paddock, by using a 1-m ruler graduated in centimeters. The sward height at each point corresponded to the mean height of the sheet curvature around the ruler.

Light interception and foliage area was performed at the pre- and post-grazing conditions with an AccuPAR Linear PAR/LAI ceptometer, Model PAR LP-80 (DECAGON Devices). Ten readings were performed in each paddock above the sward and 10 readings at the ground level (under the sward), always between 9 am and $2 \mathrm{pm}$. The percentage of sward light interception (\% LI) was observed by the T value (tau) in the equipment display and represents LI. The leaf area index was obtained by a direct reading on the same device used for LI.

The forage mass at the pre- and post-grazing conditions were estimated in the four paddocks of each module by cutting all the material at the ground level within six representative frames $\left(0.25 \mathrm{~m}^{2}\right)$. Samples were conditioned in paper bags and weighed (fresh weight) separately. Samples of each paddock were homogenized and two subsamples were collected; one of them was weighed, conditioned in paper bag and dried in a forced-ventilation oven at $55{ }^{\circ} \mathrm{C}$ until constant weight to determine the total forage mass.

The other subsample was manually separated into leaf blade, stem (stem + sheath) and dead material. Inflorescence and green leaf sheath were incorporated into the green stem fraction. The part of the leaf blade which did not present senescence signs (green organ) were incorporated into the green leaf fraction. The senescent and dead parts of the stem and leaf blade were incorporated into the dead tissue fraction. After separation, components were weighed and dried in forced-ventilation oven $\left(55{ }^{\circ} \mathrm{C}\right.$ until constant weight). Herbage accumulation rates of each morphological component were calculated by the difference between the pre- and post-grazing forage mass divided by the number of days of the regrowth period.

Data were analyzed in a completely randomized design. The $4 \times 4$ factorial (four sward height in the plot and four grazing cycles in the split-plot) defined the split-plot design. Data were subjected to analysis of variance by one way. The effect of sward height was assessed by regression analysis, while the Tukey test was used to compare averages of the grazing cycles, assuming an error rate $\alpha=0.05$.

The following model was used: $\mathrm{Y}_{\mathrm{ijk}}=\mu+\mathrm{H}_{\mathrm{i}}+\alpha_{\mathrm{ij}}+\mathrm{C}_{\mathrm{k}}+(\mathrm{HC})_{\mathrm{ij}}+\beta_{\mathrm{ijk}}, \mathrm{Y}_{\mathrm{ijk}}=$ value obtained at height $\mathrm{i}$, repetition $\mathrm{j}$ and cycle $\mathrm{k} ; \mu=$ overall average effect; $A_{i}=$ effect of the sward height $\mathrm{i}, \mathrm{i}=35,40,45$ and $50 \mathrm{~cm} ; \alpha_{\mathrm{ij}}=$ effect of random error assigned to the plot; $\mathrm{C}_{\mathrm{k}}=$ effect of the cycle $\mathrm{k}, \mathrm{k}=1,2,3$ and $4 ;(\mathrm{HC})_{\mathrm{ij}}=$ effect of the interaction height $\times$ cycle; $\beta_{\mathrm{ijk}}=$ effect of random error assigned to the split-plot of height $\mathrm{i}$, repetition $\mathrm{j}$, cycle $\mathrm{k}$.

\section{Results and Discussion}

Pasture regrowth periods adjustment linearly to pre-grazing heights $(\mathrm{P}<0.05$; Table 2$)$. There was an increase of one centimeter at the pre-grazing height for each day added to the regrowth period. Thus, the period difference between 35 and $50 \mathrm{~cm}$ pre-grazing heights was 15 days, and the longest estimated regrowth period was 88.8 days. 
Table 2. Averages of the grazing and regrowth period (day), light interception (\%), leaf area index, forage mass, leaf blade mass ( $\mathrm{kg} \mathrm{ha}^{-1}$ of DM), stem mass $\left(\mathrm{kg} \mathrm{ha}^{-1}\right.$ of DM) and dead material ( $\mathrm{kg} \mathrm{ha}^{-1}$ of DM) in the pre-grazing of Massai grass managed at different canopy height

\begin{tabular}{|c|c|c|c|c|c|c|c|c|}
\hline & \multicolumn{4}{|c|}{ Canopy height $(\mathrm{cm})$} & \multirow{2}{*}{ Mean } & \multirow{2}{*}{ s.e.m. } & \multicolumn{2}{|c|}{ Significance } \\
\hline & 35 & 40 & 45 & 50 & & & Linear & Quadratic \\
\hline Grazing period & 11.7 & 13.7 & 15.5 & 15.7 & 14.2 & 1.2 & $*$ & NS \\
\hline Regrowth period & 72.9 & 76.8 & 88.0 & 86.5 & 81.0 & 2.8 & $* * *$ & NS \\
\hline Light interception & 72.9 & 68.2 & 75.6 & 81.3 & 79.4 & 2.4 & $* *$ & $*$ \\
\hline Leaf area index & 2.7 & 2.5 & 2.9 & 3.7 & 3.1 & 0.3 & $*$ & NS \\
\hline Forage mass & 5776.1 & 6425.4 & 7540.6 & 8596.5 & 7084.6 & 407.1 & $* * *$ & NS \\
\hline Leaf blade mass & 2234.4 & 2534.2 & 2666.3 & 3145.3 & 2645.1 & 207.4 & $* *$ & NS \\
\hline Stem mass & 1017.8 & 1126.3 & 1292.4 & 1330.5 & 1191.7 & 113.4 & NS & NS \\
\hline Dead mater mass & 2523.9 & 2764.9 & 3581.8 & 4120.7 & 3247.8 & 280.8 & $* * *$ & NS \\
\hline
\end{tabular}

Note. NS, $\mathrm{P}>0.05 ; *, \mathrm{P}<0.05 ;{ }^{* *}, \mathrm{P}<0.01 ; * * *, \mathrm{P}<0.001$.

A direct linear effect was also verified with the occupation periods. There was a three days increase in the occupation period for each $10 \mathrm{~cm}$ added to the grass canopy. The shortest occupation period was 12 days, which was found to be long and inadequate because the animals start to graze the regrowth grass. The results also showed a low usage of the paddocks. Even with the shortest periods that had a pre-grazing height of $35 \mathrm{~cm}$, the paddocks were occupied only four times during the year.

The post-grazing targets equivalent to a removal of $40 \%-60 \%$ of the pre-grazing height have shown good results in tropical grasses (Silva et al., 2015). Pereira et al. (2015) also describes that severe defoliation may reduce the size and quality of the residual leaf area and decrease the rate at which the swards recover. The authors describe other experimental results: Sousa et al. (2013) studied the same response variables in Pennisetum purpureum Schum cv. Napier managed the $95 \%$ LI target associated with three post-grazing heights: 30,50 and $70 \mathrm{~cm}$. The $30 \mathrm{~cm}$ post-grazing height corresponded to $67 \%$ removal of the pre-grazing height and proved to be too severe, causing herbage accumulation to decrease and limiting the ability of plants to recover after defoliation. Under those conditions, plants showed lower rates of leaf elongation, shorter leaf lifespan, and fewer leaves per tiller and decreased final length of expanded leaves relative to the targets of 50 and $70 \mathrm{~cm}$ post-grazing height. Therefore, limitations on plants may occur when post-grazing heights represent defoliation severities greater than $60 \%$ removal of the pre-grazing height.

Based on those discussions and the post-grazing height adopted in this experiment, the intensity/severity of defoliation was probably too high. The post-grazing heights were equivalent to $57,62,67$ and $70 \%$ of the pre-grazing heights, all of them near to or above the limit for plant recovery.

Light interception (LI) had also an increase linear effect to the pre-grazing height. There was an approximately $0.6 \%$ in LI for each $\mathrm{cm}$ added to the grass sward. Cutrim Junior et al. (2011) determined that $95 \%$ of LI is the ultimate limit to the regrowth period and it must be interrupted by defoliation or cutting. However, the highest LI observed was $81.3 \%$ when the Massai guineagrass pre-grazing height was $50 \mathrm{~cm}$. Another research with $95 \%$ observed of LI with $48 \mathrm{~cm}$ of pre-grazing height (Oliveira, 2014). This research planted Massai guineagrass in lines $10 \mathrm{~cm}$ apart, in higher density than the present research and that may explain the difference of LI.

There was also a linear direct effect for LAI (Table 2) related to pre-grazing height. The highest LAI was 3.7 in the pastures with $50 \mathrm{~cm}$ in the pre-grazing height. Lara et al. (2012) described 3.6 as the optimum LAI for the Massai guineagrass during the rainy season. However, critical LAI was far behind in this research, once the LI was also under $95 \%$.

The total forage mass (FM) was adjusted to the linear regression model (Table 2). For each centimeter increase in the sward height there was an incremental increase in forage mass of $185.1 \mathrm{~kg} \mathrm{ha}^{-1}$ of DM, with the highest estimated FM being $8,396 \mathrm{~kg} \mathrm{ha}^{-1}$ for the four cycles.

Leaf blade masses in pre-grazing (LBM) answered linearly to the sward heights in the four cycles. Hare et al. (2013) observed an increase in the FM with a reduction in grazing frequency in Mombasa and Tanzania areas, but the authors did not find the same effect for LBM. This was possibly due to the large frequency amplitude of heights studied by the authors compared to the sward height worked in this study.

Stem mass $(\mathrm{StM})$ had no statistical significant difference $(\mathrm{P}>0.05)$ between sward height and had an average of 
$1,191.5 \mathrm{~kg} \mathrm{ha}^{-1}$ in pre-grazing of DM. Some authors have described low leaf elongation rate (LER) in Massai guineagrass. Rodrigues et al. (2014) and Luna et al. (2014) observed LER of 0.06 and $0.02 \mathrm{~cm}^{-1}$ during $^{-1}$ the rainy and dry seasons, respectively. In both papers, these values were the lowest among Panicum maximum cultivars studied. These results may explain the lack of pasture management effect on the StM found on this work, since such low LER was not enough to increase the StM.

The dead material mass (DMM) increased linearly with the sward height. This result can be attributed to the lifetime of the leaf; Luna et al. (2014) describe life duration of 28.5 days for Massai guineagrass. The greater pre-grazing height, the greater the time for regrowth (Table 2), and thus the greater the amount of leaf senescence before grazing. The higher the rest period, the greater the chances of pasture "passing" and leaves begin to senesce and die as reach the maximum length of life. This fact demonstrates loss of efficiency in the use of the forage as it is produced and not consumed by the animals.

The percentage of morphological components in pre-grazing did not vary with the sward heights $(\mathrm{P}>0.05)$. The mean FM fraction values of the leaf blade, stem and dead material were 37.9, 17.1 and $45.0 \%$, respectively. This fact can be explained because the LI did not exceed $95 \%$, thereby not significantly altering the sward structure.

LI did not vary among grazing cycles $(\mathrm{P}>0.05)$ and averaged $79.34 \%$. The LAI was higher only in the first cycle at heights of 45 and $50 \mathrm{~cm}$. Grazing intensity (down to $15 \mathrm{~cm}$ height) and greater need for growth may have compromised the recovery of pasture at higher pre-grazing. Higher mass and percentage of leaf blades were observed during the first grazing cycle $(\mathrm{P}<0.05)$. This result can be explained by the high intensity grazing (15 $\mathrm{cm}$ residue), thereby causing a reduction in mass in the following cycles.

The lowest percentage of stem in FM was observed in the fourth grazing cycle $(\mathrm{P}<0.05)$, this result reflects the dead material participation in this cycle (Table 3). According to Lopes et al. (2013), Massai guineagrass has a favorable genotype for leaf production, because they did not observe an increase in stem elongation rate, even with high doses of nitrogen, but the grass mostly responded to the fertilization with biomass leaf production.

Table 3. Averages of forage mass ( $\mathrm{kg} \mathrm{ha}^{-1}$ of DM), leaf blade mass ( $\mathrm{kg} \mathrm{ha}^{-1}$ of DM) and percentage (\% of FM), stem mass $\left(\mathrm{kg} \mathrm{ha}^{-1}\right.$ of DM) and percentage (\% of FM), and dead mater mass ( $\mathrm{kg} \mathrm{ha}^{-1}$ of DM) and percentage (\% of FM) at pre-grazing of Massai guineagrass at four grazing cycles

\begin{tabular}{llllllll}
\hline \multirow{2}{*}{ Variable } & \multicolumn{9}{c}{ Grazing cycle } & Mean & s.e.m. & P* $^{*}$ \\
\cline { 2 - 7 } & $1^{\mathrm{o}}$ & $2^{\mathrm{o}}$ & $3^{\mathrm{o}}$ & $4^{\mathrm{o}}$ & & & \\
\hline Forage mass & $6711.7 \mathrm{~b}$ & $7204.3 \mathrm{ab}$ & $7420.4 \mathrm{ab}$ & $7964.6 \mathrm{a}$ & 7325.3 & 331.3 & 0.036 \\
Leaf blade mass & $3416.7 \mathrm{a}$ & $2400.9 \mathrm{~b}$ & $2150.6 \mathrm{~b}$ & $2596.5 \mathrm{~b}$ & 2641.2 & 163.9 & $<0.001$ \\
Leaf blade percentage & $52.0 \mathrm{a}$ & $35.0 \mathrm{~b}$ & $30.4 \mathrm{~b}$ & $33.63 \mathrm{~b}$ & 37.8 & 1,7 & $<0.001$ \\
Stem mass & $1084.0 \mathrm{ab}$ & $1367.0 \mathrm{a}$ & $1349.9 \mathrm{a}$ & $958.9 \mathrm{~b}$ & 1189.9 & 81.8 & 0.004 \\
Stem percentage & $16.3 \mathrm{ab}$ & $20.6 \mathrm{a}$ & $19.3 \mathrm{a}$ & $12.1 \mathrm{~b}$ & 17.1 & 1,1 & $<0.001$ \\
Dead leaf mass & $2084.0 \mathrm{c}$ & $2974.2 \mathrm{bc}$ & $3637.6 \mathrm{ab}$ & $4372.3 \mathrm{a}$ & 3267.0 & 246.4 & $<0.001$ \\
Dead leaf percentage & $31.7 \mathrm{c}$ & $44.3 \mathrm{~b}$ & $50.3 \mathrm{ab}$ & $54.2 \mathrm{a}$ & 45.1 & 1.7 & $<0.001$ \\
\hline
\end{tabular}

Note. Different lowercase letters differ between columns (*Tukey test).

The mass and the percentage of dead leaves in pre-grazing increased with the grazing cycles, and reached $4,372.30 \mathrm{~kg} \mathrm{ha}^{-1} \mathrm{DM}$ in the last cycle (Table 3). The high density of tillers of the Massai guineagrass (Luna et al., 2016) hinders the dead leaves and stems peeling off, thus remaining over successive grazing cycles. This excessive increase in dead material mass suggest a loss of efficiency in the production of fodder with the advance of grazing cycles, since the FM followed the same pattern.

Post-grazing light interception (LIr) had quadratic response to the pre-grazing heights (Table 4). The lowest LI was $29.42 \%$ at $42.05 \mathrm{~cm}$ high. The residual leaf area index (LAIr) also had a quadratic response, with a minimum post-grazing point obtained at $41.85 \mathrm{~cm}$ high, with LAIr of 0.69 . The higher values of LAIr and LIr observed on the lowest and highest heights may be explained by the relation of size/tillering (Sbrissia \& Silva, 2008). 
Table 4. Averages of light interception (\%), leaf area index, forage mass ( $\mathrm{kg} \mathrm{ha}^{-1}$ of DM), leaf blade mass ( $\mathrm{kg} \mathrm{ha}^{-1}$ of DM), stem mass $\left(\mathrm{kg} \mathrm{ha}^{-1}\right.$ of DM) and dead mater mass $\left(\mathrm{kg} \mathrm{ha}^{-1}\right.$ of $\left.\mathrm{DM}\right)$ at post-grazing of Massai grass managed at different canopy heights

\begin{tabular}{|c|c|c|c|c|c|c|c|c|}
\hline & \multicolumn{4}{|c|}{ Canopy height $(\mathrm{cm})$} & \multirow{2}{*}{ Mean } & \multirow{2}{*}{ s.e.m. } & \multicolumn{2}{|c|}{ Significance } \\
\hline & 35 & 40 & 45 & 50 & & & Linear & Quadratic \\
\hline Light interception & 36.8 & 33.4 & 28.6 & 41.3 & 35.0 & 2.0 & NS & $* * *$ \\
\hline Leaf area index & 0.9 & 0.8 & 0.7 & 1.1 & 0.9 & 0.1 & NS & $* *$ \\
\hline Forage mass & 4428.3 & 4509.1 & 4665.8 & 5053.7 & 4664.2 & 344.2 & $*$ & NS \\
\hline Leaf blade mass & 365.1 & 338.9 & 457.1 & 246.6 & 351.9 & 62.0 & NS & NS \\
\hline Stem mass & 964.2 & 943.1 & 850.3 & 889.1 & 911.7 & 107.3 & NS & NS \\
\hline Dead mater mass & 3099.0 & 3227.2 & 3358.5 & 3918.0 & 3400.7 & 315.1 & $*$ & NS \\
\hline
\end{tabular}

Note. NS, $\mathrm{P}>0.05 ; *, \mathrm{P}<0.05 ; * *, \mathrm{P}<0.01 ; * * *, \mathrm{P}<0.001$.

According to Cutrin Junior et al. (2011), higher LAIr was associated with greater participation of leaf blades and consequently reduction in the regrowth period due to lower use of organic reserves. However, higher LAIr also promoted higher coefficient of light extinction, which can contribute to reducing tiller density. These authors observed an increase of four days in the regrowth period of Tanzania guineagrass when it was managed from LAIr of 1.8 to 1.0 .

The forage mass in the post-grazing (FMr) linearly increased in response to pre-grazing heights in the pastures managed with pre-grazing height of $50 \mathrm{~cm}$, where $5.279 \mathrm{~kg} \mathrm{ha}^{-1}$ of DM was obtained (Table 4). Data obtained in this study were higher than those described by Emerenciano Neto et al. (2013), when FMr of Massai guineagrass had $4.350 \mathrm{~kg} \mathrm{ha}^{-1}$ of DM with post-grazing height of $25 \mathrm{~cm}$. The authors considered $25 \mathrm{~cm}$ PGh too high since the trend of the mass was to die.

There was no effect of the pre-grazing heights in the stubble leaf blade mass (LBMr) $(\mathrm{P}>0.05)$, which had an average of $352.0 \mathrm{~kg} \mathrm{ha}^{-1}$ of DM. The LBMr was lower than that observed by Emerenciano Neto et al. (2013) due to the higher post-grazing height used by the authors, who found $764.1 \mathrm{~kg} \mathrm{ha}^{-1} \mathrm{DM}$ at $25 \mathrm{~cm}$ high. According to Lopes et al. (2011), the remaining amount of leaves indicated the level of the animals grazing pressure. Thus, the small amount of remaining leaves indicated that the grazing pressure was high.

According to Pedreira et al. (2015), the leaf blades presented in the post-grazing is photosynthetically active than the expanding ones. Lower participation of the leaf blades in the post-grazing dramatically reduced the photosynthetic rate of plants during regrowth caused by the sharp drop in the reducing sugars represented by the monosaccharides glucose and fructose, which are the first stable organic compounds synthesized by plants during photosynthesis (Alexandrino et al., 2008). According to Lopes et al. (2011), the largest leaf blade mass in post-grazing resulted in better regrowth condition for the plants. This decreased the participation of the stem reserves to form new leaves and quickly restored the total non-structural carbohydrates, hence reducing the pasture regrowth period.

Therefore, the $15 \mathrm{~cm}$ post-grazing target for Massai guineagrass may not be ideal because at higher post-grazing heights greater participation of leaf blades can reduce the regrowth period (Table 2), which can make the grazing process more dynamic and sustainable.

Post-grazing stem mass (StMr) did not vary with the pre-grazing height $(\mathrm{P}>0.05)$. Since the post-grazing height not vary among treatments, the StMr did not vary and had an average of $911.5 \mathrm{~kg} \mathrm{ha}^{-1} \mathrm{DM}$. This can be explained because the stem is a structural component that reflects on sward height.

Dead material mass (DMMr) had positive linear response, with a maximum estimated value of $3,788 \mathrm{~kg}^{-1}$ of DM obtained in the pasture managed at $50 \mathrm{~cm}$ in the pre-grazing height. Increasing the plant height in the target pre-grazing from 35 to $50 \mathrm{~cm}$, there was a reduction in the quantity and quality of radiation that reached the plant leaf blades located in the base of the sward. According to Guimenes et al. (2011), this decreased the density of the green leaf blade dry mass and increased stem and dead material density. Since the stem was eaten by the animals during grazing, the excess of dead material remained after defoliation.

The percentage of morphological components in the post-grazing did not vary according to the pre-grazing heights $(\mathrm{P}>0.05)$. The mean FM values of leaf blade, stem and dead material were 7.7, 20.2 and 72.1\%, respectively. The great amount of dead material was the major obstacle in the management of the Massai guineagrass, because it meant loss of efficiency in pasture use. This component was the fraction that was 
produced but not consumed, joining the nutrient cycling, but because of the low quality of the nutrients, it did not bring a significant increase in soil fertility (Emerenciano Neto et al., 2013).

There were no effects of the cycles in the LIr $(\mathrm{P}>0.05)$, which had an average of $34.8 \%$. LAIr and stem percentage $(\mathrm{Sr})$ varied with grazing cycles $(\mathrm{P}<0.05)$. The average post-grazing sward height reduced with the grazing cycles, from $16.4 \mathrm{~cm}$ to $14.7 \mathrm{~cm}$ in the last cycle. This can be attributed to intensive grazing to reach the $15 \mathrm{~cm}$ post-grazing height. LAIr decreased with the grazing cycles $(\mathrm{P}<0.05)$, with the largest LAIr being observed in the first cycle (1.049) and the lowest in the third (0.751).

Grazing cycles had no effect on the post-grazing masses. Total forage, leaf blade, stem and dead material had averages of 4711, 344, 923, and $3324 \mathrm{~kg} \mathrm{ha}^{-1} \mathrm{DM}$, respectively. Stem percentage in post-grazing was higher in the first and lower in the fourth cycle, thus reflecting sward height. There was no effect on the percentage of leaf blade and dead material, which were 7.7 and $71.5 \%$, respectively.

DM and dead material had linear response, with the largest being 58.32 and $20.46 \mathrm{~kg} \mathrm{ha}^{-1} \mathrm{day}^{-1} \mathrm{DM}$, respectively (Table 5). Similar values (56.16 kg ha ${ }^{-1}$ day $^{-1} \mathrm{DM}$ ) were found by Luna et al. (2014) cutting Massai guineagrass every 30 days. Emerenciano Neto et al. (2013) observed accumulation rate of $73.4 \mathrm{~kg} \mathrm{ha}^{-1} \mathrm{day}^{-1} \mathrm{DM}$ for Massai guineagrass grazed by sheep and managed to 25 and $50 \mathrm{~cm}$ heights in the post and pre-grazing, respectively. The lower results obtained in this study were probably due to the high pressure grazing (down to $15 \mathrm{~cm}$ ), with less amount of leaf blades after grazing.

Table 5. Averages of dry mater accumulation rate, leaf blade, stem and dead material in Massai grass pastures under different canopy heights

\begin{tabular}{lllllllll}
\hline & \multicolumn{4}{c}{ Canopy height $(\mathrm{cm})$} & \multirow{2}{*}{ Mean } & s.e.m. & \multicolumn{2}{c}{ Significance } \\
\cline { 2 - 5 } & 35 & 40 & 45 & 50 & & & Linear & Quadratic \\
\hline Dry mater $\left(\mathrm{kg} \mathrm{ha}^{-1}\right.$ day $\left.^{-1}\right)$ & 30.8 & 39.6 & 37.7 & 64.9 & 43.3 & 6.2 & $* *$ & NS \\
Leaf blade $\left(\mathrm{kg} \mathrm{ha}^{-1} \mathrm{day}^{-1}\right)$ & 23.9 & 30.3 & 22.2 & 33.4 & 27.4 & 3.8 & $\mathrm{NS}$ & NS \\
Stem $\left(\mathrm{kg} \mathrm{ha}^{-1}\right.$ day $\left.^{-1}\right)$ & 0.2 & 2.8 & 4.6 & 4.2 & 3.0 & 2.7 & $\mathrm{NS}$ & NS \\
Dead mater $\left(\mathrm{kg} \mathrm{ha}^{-1}\right.$ day $\left.^{-1}\right)$ & 6.6 & 6.6 & 13.9 & 22.3 & 12.4 & 5.1 & $*$ & NS \\
\hline
\end{tabular}

Note. NS, $\mathrm{P}>0,05 ; *, \mathrm{P}<0,05 ; * *, \mathrm{P}<0,01$.

Average rates of leaf blade and stem accumulation were not affected by pre-grazing height, with averages of 27.4 and $2.92 \mathrm{~kg} \mathrm{ha}^{-1}$ day $^{-1}$ of MS, respectively. Forage accumulation is the result of the net balance between the production of new tissues by the plant and loss of older tissues by senescence, so the accumulation results of the components show reduction in liquid forage accumulation with increasing height. This is because accumulated dead material mass moves from 14.92 to $35.23 \%$ of the total forage mass when compared to the heights of 35 to $50 \mathrm{~cm}$, respectively. In a condition of zero net accumulation, the cumulative percentage of dead material would be $50 \%$, so for each accumulated green component mass, the same mass was lost by senescence. Difante et al. (2011) observed higher total forage, leaf blades and stem accumulation in Brachiaria brizantha cv. Marandu cut at $15 \mathrm{~cm}$ high and in different cutting intervals, being attributed to the growing rate and leaf elongation. Accumulation rates did not differ between grazing cycles. The lack of seasonality in forage production demonstrated efficiency in the rational use of irrigation because it kept the pasture physiologically active over the seasons.

\section{Conclusion}

Massai guineagrass grazed by sheep must be handled between 35 and $40 \mathrm{~cm}$ high at pre-grazing when associated with post-grazing height of $15 \mathrm{~cm}$. When the pre-grazing height was higher than $40 \mathrm{~cm}$, there was accumulation of dead material, which was responsible for increasing the forage mass.

\section{References}

Alexandrino, E., Mosquim, P. R., Nascimento Júnior, D., Vaz, R. G. M. V., \& Detmann, E. (2008). Evolução da biomassa e do perfil da reserva orgânica durante a rebrotação da Brachiaria brizantha cv. Marandu submetida a doses de nitrogênio. Revista Brasileira de Saúde e Produção Animal, 9(2), 190-200. Retrieved from http://revistas.ufba.br/index.php/rbspa/article/viewArticle/1103 
Cardoso, S., Volpe, E., \& Macedo, M. C. M. (2016). Effect of nitrogen and lime on Massai grass subjected to intensive cutting. Pesquisa Agropecuária Tropical, 46(1), 19-27. https://doi.org/10.1590/1983-40632016 v4638132

Cutrim Junior, J. A. A., Cândido, M. J. D., Valente, B. S. M., Carneiro, M. S. S., \& Carneiro, H. A. V. (2011). Características estruturais do dossel de capim-tanzânia submetido a três frequências de desfolhação e dois resíduos pós-pastejo. Revista Brasileira de Zootecnia, 40(3), 489-497. https://doi.org/10.1590/S1516-3 5982011000300005

Difante, G. S., Euclides, V. P. B., Nascimento Júnior, D., Silva, S. C., Barbosa, R. A., \& Torres, Junior, R. A. A. (2010). Desempenho e conversão alimentar de novilhos de corte em capim-tanzânia submetido a duas intensidades de pastejo sob lotação rotativa. Revista Brasileira de Zootecnia, 39(1), 33-41. https://doi.org/10.1590/S1516-35982010000100005

Difante, G. S., Nascimento Júnior, D., Silva, S. C., Euclides, V. P. B., Montagner, D. B., Silveira, M. C. T., et al. (2011). Características morfogênicas e estruturais do capim-marandu submetido a combinações de alturas e intervalos de corte. Revista Brasileira de Zootecnia, 40(5), 955-963. https://doi.org/10.1590/S1516-35982 011000500003

Empresa Brasileira de Pesquisa Agropecuária (EMBRAPA). (2006). Sistema brasileiro de classificação de solos (2nd ed., p. 306). Rio de Janeiro.

Emerenciano Neto, J. V., Difante, G. S., Montagner, D. B., Bezerra, M. G. S., Galvão, R. C. P., \& Vasconcelos, R. I. G. (2013). Características estruturais do dossel e acúmulo de forragem em gramíneas tropicais, sob lotação intermitente e pastejada por ovinos. Bioscience Journal, 29(4), 962-973. Retrieved from http://www.seer.ufu.br/index.php/biosciencejournal/article/view/17393/12917

Euclides, V. P. B., Macedo, M. C. M., Zimmer, A. H., Jank, L., \& Oliveira, M. P. (2008). Avaliação dos capins mombaça e massai sob pastejo. Revista Brasileira de Zootecnia, 37(1), 18-26. https://doi.org/10.1590/ S1516-35982008000100003

Euclides, V. P. B., Montagner, D. B., Difante, G. S., Barbosa, R. A., \& Fernandes, W. S. (2014). Sward structure and livestock performance in guinea grass cv. Tanzania pastures managed by rotational stocking strategies. Scientia Agricola, 71(6), 451-457. https://doi.org/10.1590/0103-9016-2013-0272

Gimenes, F. M. A., Silva, S. C., Fialho, C. A., Gomes, M. B., Berndt, A., Gerdes, L., et al. (2011). Ganho de peso e produtividade animal em capim-marandu sob pastejo rotativo e adubação nitrogenada. Pesquisa Agropecuária Brasileira, 46(7), 751-759. https://doi.org/10.1590/S0100-204X2011000700011

Hare, M. D., Phengphet, S., Songsiri, T., Sutin, N., \& Stern, E. (2013). Effect of cutting interval on yield and quality of two Panicum maximum cultivars in Thailand. Tropical Grasslands - Forrajes Tropicales, 1(1), 87-89. https://doi.org/10.17138/TGFT(1)87-89

Lara, M. A. S., Pedreira, C. G. S., Boote, K. J., Pedreira, B. C., Moreno, L. S. B., \& Alderman, P. D. (2012). Predicting Growth of Panicum maximum: An Adaptation of the CROPGRO Perennial Forage Model. Agronomy Journal, 104(3), 600-611. https://doi.org/10.2134/agronj2011.0272

Lemaire, G., Silva, S. C., Agnusdei, M., Wade, M., \& Hodgson, J. (2009). Interactions between leaf lifespan and defoliation frequency in temperate and tropical pastures: A review. Grass and Forage Science, 64(4), 341-353. https://doi.org/10.1111/j.1365-2494.2009.00707.x

Lima, M. L. P., Simili, F. F., Giacomini, A., Roma Junior, L. C., Ribeiro, E. G., \& Paz, C.C.P. (2013). Rotational stocking management affects the structural and nutritional characteristics of Guinea grass swards and milk productivity by crossbred dairy cows. Animal Feed Science and Technology, 186(4), 131-138. https://doi.org/10.1016/j.anifeedsci.2013.10.002

Lopes, M. N., Cândido, M. J. D., Pompeu, R. C. F. F., Silva, R. G., \& Bezerra, F. M. L. (2011). Componentes estruturais do resíduo pós-corte em capim-massai adubado com cinco doses de nitrogênio. Revista Ciência Agronômica, 42(2), 518-525. https://doi.org/10.1590/S1806-66902011000200035

Lopes, M. N., Cândido, M. J. D., Pompeu, R. C. F. F., Silva, R. G., Lopes, J. W. B., Fernandes, F. R. B., et al. (2013). Fluxo de biomassa em capim-massai durante o estabelecimento e rebrotação com e sem adubação nitrogenada. Revista Ceres, 60(3), 363-371. https://doi.org/10.1590/S0034-737X2013000300009

Luna, A. A., Difante, G. S., Montagner, D. B., Emerenciano Neto, J. V., Araújo, I. M. M., \& Oliveira, L. E. C. (2014). Características morfogênicas e acúmulo de forragem de gramíneas forrageiras, sob corte. Bioscience 
Journal, 30(6), 1803-1810. Retrieved from http://www.seer.ufu.br/index.php/biosciencejournal/article/view/ $22260 / 15618$

Luna, A. A., Difante, G. S., Montagner, D. B., Emerenciano Neto, J. V., Araújo, I. M. M., \& Fernandes, L. S. (2016). Tillering dynamic and structural characteristics of tropical grasses under cutting management. Bioscience Journal, 32(4), 1008-1017. https://doi.org/10.14393/BJ-v32n4a2016-32944

Oliveira, D. R. (2014). Morphogenesis and interception of solar radiation incident on massaigrass intercropped with pasture forage peanut in cuts (Unpublished master's dissertation). Federal University of Lavras, Lavras, Brazil.

Pedreira, B. C., Pedreira, C. G. S., \& Silva, S. C. (2009). Acúmulo de forragem durante a rebrotação de capim-xaraés submetido a três estratégias de desfolhação. Revista Brasileira de Zootecnia, 38(4), 618-625. https://doi.org/10.1590/S1516-35982009000400005

Pedreira, B. C., Pedreira, C. G. S., \& Lara, M. A. S. (2015). Leaf age, leaf blade portion and light intensity as determinants of leaf photosynthesis in Panicum maximum Jacq. Grassland Science, 61(1), 45-49. https://doi.org/10.1111/grs. 12080

Pereira, L. E. T., Paiva, A. J., Geremia, E. V., \& Silva, S. C. (2015). Regrowth patterns of elephant grass (Pennisetum purpureum Schum) subjected to strategies of intermittent stocking management. Grass and Forage Science, 70(1), 195-204. https://doi.org/10.1111/gfs.12103

Rodrigues, R. C., Sousa, T. V. R., Melo, M. A. A., Araújo, J. S., Lana, R. P., Costa, C. S., et al. (2014). Agronomic, morphogenic and structural characteristics of tropical forage grasses in northeast Brazil. Tropical Grasslands - Forrajes Tropicales, 2(2), 214-222. https://doi.org/10.17138/TGFT(2)214-222

Sbrissia, A. F., \& Silva, C. S. (2008). Compensação tamanho/densidade populacional de perfilhos em pastos de capim-marandu. Revista Brasileira de Zootecnia, 37(1), 35-47. https://doi.org/10.1590/S1516-359820080 00100005

Silva, A. S., Laura, V. A., \& Jank, L. (2009). Soil flood tolerance of seven genotypes of Panicum maximum Jacq. Brazilian Archives of Biology and Technology, 52(6), 1341-1348. https://doi.org/10.1590/S1516-891320090 00600004

Silva, S. C., Sbrissia, A. F., \& Pereira, L. E. T. (2015). Ecophysiology of C4 Forage Grasses-Understanding Plant Growth for Optimising Their Use and Management. Agriculture, 5(3), 598-625. https://doi.org/10.3390/ agriculture 5030598

Sousa, B. M. L., Nascimento Júnior, D., Monteiro, H. C. F., Silva, S. C., Vilela, H. H., Silveira, M. C. T., et al. (2013). Dynamics of forage accumulation in Elephant grass subjected to rotational grazing intensities. Revista Brasileira de Zootecnia, 42(9), 629-638. https://doi.org/10.1590/S1516-35982013000900004

Thornthwaite, C. W. (1948). An approach toward a rational classification of climate. Geogr. Rev., 38, 55-94. https://doi.org/10.2307/210739

\section{Copyrights}

Copyright for this article is retained by the author(s), with first publication rights granted to the journal.

This is an open-access article distributed under the terms and conditions of the Creative Commons Attribution license (http://creativecommons.org/licenses/by/4.0/). 